\title{
IMPACT OF STANDARD WORK FOR LEADERS ON REDUCING UNUSED EMPLOYEE CREATIVITY DURING LEAN IMPLEMENTATION
}

\author{
M. Mogaramedi ${ }^{1}$, H. Nel ${ }^{1^{*}}$ \& A. Marnewick ${ }^{1}$
}

\section{ARTICLE INFO}

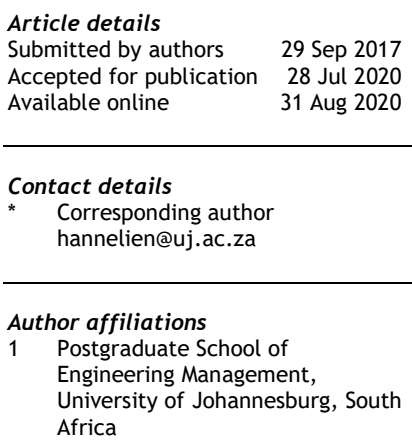

DOI

http://dx.doi.org/10.7166/31-2-1842
Organisations implement lean in production to improve continuously, but implementation may be unsuccessful due to ineffective leadership. Also, organisations have not eliminated the eighth lean waste - namely, the waste of unused employee creativity. The research investigated standard work for leaders in reducing unused employee creativity. The case study, conducted in an automobile manufacturer, indicated that worker ideas increased when employees were trained in lean, and when standard work for leaders was implemented. The research concluded that standard work for leaders reduces the waste of unused employee creativity, and suggests a lean implementation model that can be validated with further work.

\section{OPSOMMING}

Maatskappye implementeer lenige vervaardigingsbeginsels om aanhoudend te verbeter, maar die implementering mag onsuksesvol wees as gevolg van oneffektiewe leierskap. Maatskappye implementeer ook selde die agtste lenige vermorsing, naamlik die vermorsing van werknemers se kreatiwiteit. Hierdie navorsing ondersoek tegnieke vir leiers om dié vermorsing aan te spreek. Die gevallestudie, wat by 'n motorvervaardiger van stapel gestuur is, het aangedui dat werker idees toegeneem het wanneer werknemers opgelei is aan die hand van lenige vervaardiging en wanneer gestandaardiseerde werk vir leiers implementeer is. Die gevolgtrekking is dat gestandaardiseerde werk vir leiers die vermorsing van werknemer kreatiwiteit verminder en stel 'n lenige implementeringsmodel voor wat met toekomstige werk gevalideer kan word.

\section{INTRODUCTION}

Many organisations have attempted to implement lean production [1]. However, these attempts often fail to realise the same benefits that were experienced by the Toyota Motor Company (hereafter referred to as 'Toyota'). This is primarily because people only concentrate on the visible attributes of lean (including lean tools, practices, and principles) instead of on the invisible attributes of lean, such as leadership and creativity [2].

Rother [2] stated that the invisible attributes of lean are inclusive of the actions, routines, and thought patterns of the leaders in the organisation. These invisible lean attributes make up 80 per cent of lean production [3]. Mann [4] defines these invisible lean attributes as 'standard work for leaders' - a defined set of tasks or activities that leaders perform daily [5].

It is the norm for production workers to work according to standard work in order to produce stable and consistent results [6]. Unfortunately, many leaders do not work according to any defined or standard work [7]. As a result, the actions of leaders are often inconsistent with the messages about continuous improvement and problem-solving that they communicate to their workers [7].

Effective and efficient organisations are highly reliant on the ingenuity of their human resources [8]. Employee creativity is needed to develop innovative solutions for the numerous problems that organisations 
face. However, not all organisations take advantage of the ingenuity of their employees. A study by Liker and Meier [9] concluded that unused employee creativity is one of the eight types of lean waste.

'Unused employee creativity' refers to the numerous ideas, implicit knowledge, and improvement opportunities that organisations forfeit simply because they do not involve their workers in continuous improvement efforts $[9,10]$. As a result the employees keep their ideas to themselves while the organisation continues to face problems for which their own employees may have the knowledge to resolve. If it can be reasonably assumed that people are at the heart of lean production [11], standard work for leaders is critical to the sustainable implementation of lean. However, little research has been conducted to date on the subject of standard work for leaders, nor on its connection with employee creativity.

The purpose of this study was to investigate the impact of standard work for leaders on reducing the waste of unused employee creativity during lean implementation. The case study was conducted in a South African automobile manufacturer in four production departments - physical logistics, the body shop, the paint shop, and assembly. The research objectives were defined as follows: to determine which of the four departments had implemented standard work for leaders effectively; and to investigate which of the four departments had suggested the most ideas.

\section{LITERATURE REVIEW}

\subsection{Lean management}

Lean production views the role of the leader as that of an enabler [14], while the responsibility for solving problems and improving processes lies with the workers. The challenge that lean leaders thus face is that of providing support to workers, and of actively engaging with them so that they can improve their work processes and reduce waste. Toyota views the role of leadership as an enabler rather than as a process improver [14]. Toyota places the responsibility for continuous improvement with the workers; the leader's role becomes that of a coach rather than instructor [14].

Mann [4] defines the constituents of the lean management system as shown in Figure 1.

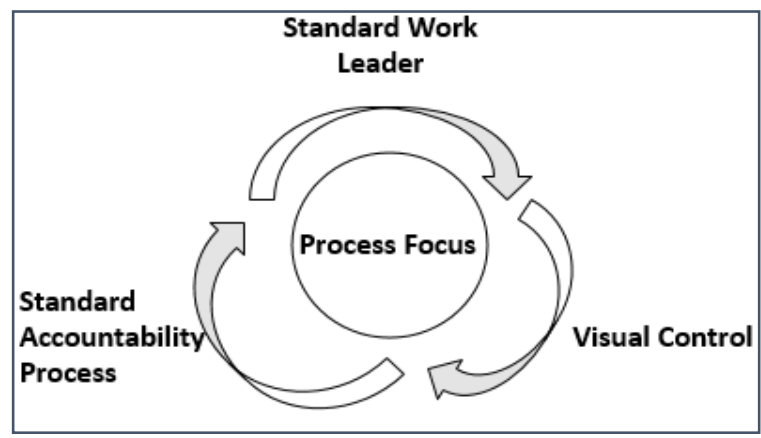

Figure 1: Lean management system as a closed loop system [4]

The closed loop lean management system emphasises the feedback and interaction required for process improvement. The element 'standard work for leaders' is considered integral to the lean management system, and specifies the activities that leaders must perform daily [5].

'Standard work leader': Production workers are normally able to produce stable and consistent results; the same consistency can be expected from the standard work for leaders, since leadership is reliant on the process and not the person [6]. Unfortunately, unlike production workers, many leaders do not practise standardised work [7]. Their actions are therefore inconsistent with the message of continuous improvement and problem-solving [7].

'Visual controls' in the lean management system enable the organisation to concentrate on the performance of the processes. Through the use of visual controls, the planned process performance can be compared with the actual process performance clearly and unambiguously.

The 'standard accountability process' refers to a standardised timeslot in the form of a meeting structure that enables timeous feedback on all assigned tasks [5]. In certain organisations, these meetings are usually conducted at the same time on a recurring basis and with an unvarying agenda. 


\subsection{Production waste}

In their book The Toyota way fieldbook: A practical guide for implementing Toyota's 4Ps, Liker and Meier [9] define eight main types of waste that can be found in any process, regardless of the organisation or industry. These are overproduction, waiting time, transport, over-processing or incorrect processing, excessive inventories, unnecessary movements, defects, and unused employee creativity. The eighth waste - unused employee creativity - was not included as one of the wastes that Taiichi Ohno from Toyota had originally defined [12]. Interestingly, unused employee creativity is the only human-specific waste of lean; the others are process-specific.

\subsubsection{Unused employee creativity}

The role of leadership is to provide direction and a sense of purpose to the organisation [13]. Leadership can be demonstrated in various ways, including showing respect to workers while communicating with them; challenging employees to develop their own ideas for improvement; and being appreciative of initiative and creativity [13].

The implication of unused employee creativity is that organisations do not benefit from the intelligence and creativity of their workers, simply because the workers have not been engaged accordingly. It is common for organisations to have an external or internal team of specialists and managers whose role it is to improve the processes and to solve problems. However, this is not how Toyota views the role of its leaders; neither is this practice aligned with the objectives of lean production.

The initial seven wastes defined by Ohno also contribute significantly to unused employee creativity [9]. His argument was that the seven wastes - such as overproduction and over- processing - obscure problems, and so do not challenge the workers in creative problem-solving [9]. However, when these wastes are reduced or eliminated, production problems become visible, enabling employees to think of creative solutions [9]. The premise of emphasising the eighth waste is that, if the only people who are responsible for continuous improvement are the leaders, then the organisation is doing itself a disservice by overlooking creative ideas that can improve organisational processes [9].

A second supporting premise for identifying the waste of unused employee creativity is that the people who are working on the process are inherently the experts of the process [9]. Consequently they have the knowledge and ideas to improve their own work environment; and it is the role of organisational leadership to create a climate that will encourage such improvement initiatives among the employees.

\subsection{Standard work for leaders}

The critical element in standard work is having a daily schedule of the different activities that must be carried out by the different leaders [7]. The details of when to do which activity, and the actual activities, may vary from organisation to organisation. Mann [4] suggested that the routines, tools, and behaviours of leadership have to be clearly defined and standardised. The organisation could achieve a comprehensive cultural change and re-enforce a focus on aspects of work that may not previously have been considered important [15]. However, not all organisations have defined their leadership activities in detail; and this only produces an incomplete lean management system [4]. Clearly defined leadership ensures that the various tools and methods in the lean toolbox have the required lean thinking and mind-set to support it [4], so that lean becomes a habitual action rather than a discrete activity [16].

\subsubsection{Schedule of standard work for leaders}

A major part of ensuring adherence to standardised work lies in compiling a binding daily schedule for all the different levels of the organisation. This schedule is specific to each production environment and to each company. It encompasses the different activities that ought to be done, the people responsible for executing those activities, and the time frame for carrying out those activities. Table 1 below illustrates a typical standard work schedule. 
Table 1: General schedule for standard work for leaders (derived from [6,9])

\begin{tabular}{|c|c|c|c|c|c|}
\hline Time & Team Members & Hancho & Team Leaders & Managers & Senior Managers \\
\hline $\begin{array}{l}\text { Before } \\
\text { shift }\end{array}$ & $\begin{array}{l}\text { Ensure production } \\
\text { capability before } \\
\text { start of shift }\end{array}$ & $\begin{array}{l}\text { Confirm } \\
\text { manpower }\end{array}$ & $\begin{array}{l}\text { Shift change } \\
\text { coordination and } \\
\text { general } \\
\text { administrative } \\
\text { work }\end{array}$ & $\begin{array}{l}\text { Daily } \\
\text { administra-tive } \\
\text { duties }\end{array}$ & $\begin{array}{l}\text { Review } \\
\text { performance } \\
\text { trends }\end{array}$ \\
\hline $\begin{array}{l}\text { Before } \\
\text { shift }\end{array}$ & $\begin{array}{l}\text { Attend core team } \\
\text { start up meeting }\end{array}$ & $\begin{array}{l}\text { Conduct start-up } \\
\text { core team } \\
\text { meeting }\end{array}$ & $\begin{array}{l}\text { Attend core team } \\
\text { start up meeting }\end{array}$ & $\begin{array}{l}\text { Spot check, } \\
\text { sign off on } \\
\text { visual controls }\end{array}$ & $\begin{array}{l}\text { Spot check, sign off } \\
\text { on visual controls }\end{array}$ \\
\hline $\begin{array}{l}\text { Shift } \\
\text { start }\end{array}$ & $\begin{array}{l}\text { Perform regular } \\
\text { job duties } \\
\text { according to the } \\
\text { standardised } \\
\text { work. }\end{array}$ & $\begin{array}{l}\text { Conduct } \\
\text { production start- } \\
\text { up floor check }\end{array}$ & $\begin{array}{l}\text { Conduct } \\
\text { production start- } \\
\text { up floor check }\end{array}$ & & \\
\hline $\begin{array}{l}\text { During } \\
\text { shift }\end{array}$ & $\begin{array}{l}\text { Activate and on } \\
\text { call if a problem } \\
\text { arises or has an } \\
\text { improvement idea }\end{array}$ & $\begin{array}{l}\text { Respond to and } \\
\text { on calls from } \\
\text { team members }\end{array}$ & $\begin{array}{l}\text { Respond to } \\
\text { problems and } \\
\text { escalate major } \\
\text { problems to } \\
\text { manager. }\end{array}$ & $\begin{array}{l}\text { Lead } \\
\text { improvement } \\
\text { team meeting }\end{array}$ & $\begin{array}{l}\text { Lead weekly plant } \\
\text { performance and } \\
\text { improvement } \\
\text { review meetings. }\end{array}$ \\
\hline \multirow[t]{3}{*}{$\begin{array}{l}\text { During } \\
\text { shift }\end{array}$} & \multirow{3}{*}{$\begin{array}{l}\text { Communicate } \\
\text { improvement } \\
\text { ideas to hancho } \\
\text { and team leader }\end{array}$} & \multirow{3}{*}{$\begin{array}{l}\text { Attend tier } 2 \\
\text { Team leader } \\
\text { meeting }\end{array}$} & $\begin{array}{l}\text { Conduct tier } 2 \\
\text { meeting }\end{array}$ & \multirow{3}{*}{$\begin{array}{l}\text { Floor time } \\
\text { (Coaching \& } \\
\text { Training) }\end{array}$} & \multirow[t]{3}{*}{$\begin{array}{l}\text { Verify leader } \\
\text { standard work }\end{array}$} \\
\hline & & & $\begin{array}{l}\text { Production } \\
\text { challenges and } \\
\text { improvements }\end{array}$ & & \\
\hline & & & $\begin{array}{l}\text { Open topics and } \\
\text { arising topics }\end{array}$ & & \\
\hline $\begin{array}{l}\text { During } \\
\text { shift }\end{array}$ & & $\begin{array}{l}\text { Gemba walk with } \\
\text { Team Leader }\end{array}$ & $\begin{array}{l}\text { Gemba walk with } \\
\text { hancho }\end{array}$ & $\begin{array}{l}\text { Gemba walk } \\
\text { with Team } \\
\text { Leader }\end{array}$ & $\begin{array}{l}\text { Verify hancho and } \\
\text { team leaders are } \\
\text { on the shopfloor } \\
\text { and follow up if } \\
\text { they are not. }\end{array}$ \\
\hline $\begin{array}{l}\text { During } \\
\text { shift }\end{array}$ & & $\begin{array}{l}\text { Accountability \& } \\
\text { Process } \\
\text { Improvement } \\
\text { meeting }\end{array}$ & $\begin{array}{l}\text { Review production } \\
\text { status }\end{array}$ & & $\begin{array}{l}\text { Gemba walk with } \\
\text { each manager }\end{array}$ \\
\hline $\begin{array}{l}\text { During } \\
\text { shift }\end{array}$ & & $\begin{array}{l}\text { Continuous } \\
\text { improvement } \\
\text { meeting with } \\
\text { hanchos }\end{array}$ & $\begin{array}{l}\text { Floor time } \\
\text { (Coaching \& } \\
\text { Training) }\end{array}$ & & $\begin{array}{l}\text { Floor time } \\
\text { (Coaching \& } \\
\text { Training) }\end{array}$ \\
\hline \multirow[t]{3}{*}{$\begin{array}{l}\text { During } \\
\text { shift }\end{array}$} & & $\begin{array}{l}\text { Verify shift } \\
\text { performance }\end{array}$ & & & \\
\hline & & $\begin{array}{l}\text { Record variations } \\
\text { \& reasons }\end{array}$ & & & \\
\hline & & $\begin{array}{l}\text { Act on recurring } \\
\text { interrupters. }\end{array}$ & & & \\
\hline \multirow[t]{3}{*}{$\begin{array}{l}\text { During } \\
\text { shift }\end{array}$} & & $\begin{array}{l}\text { Conduct process } \\
\text { confirmation on } \\
\text { each work station }\end{array}$ & & & \\
\hline & & $\begin{array}{l}\text { Confirm if team } \\
\text { member works } \\
\text { according to } \\
\text { process }\end{array}$ & & & \\
\hline & & $\begin{array}{l}\text { Conduct } \\
\text { corrective } \\
\text { measures if } \\
\text { needed. }\end{array}$ & & & \\
\hline
\end{tabular}

The schedule of work is primarily broken into three distinct time frames: activities done before the start of the shift; activities done during the shift; and activities done at the end of the shift. The concept of standard work for leaders is developed, based on the standard work elements of the production team members on the shop floor [6]. Having different levels of leadership working according to standard work ensures that the necessary support is given to each level - particularly support for continuous improvement initiatives. 
The research investigated the impact that standard work for leaders has on reducing the eighth lean waste (unused employee creativity). The case study was selected as the appropriate research method for a practical investigation of an existing phenomenon within the confines of its actual setting [17]. The case study provided the researchers with comprehensive information about the subject of the study [18]. For the purposes of this research, a single case design was selected. The use of single case design is often employed due to its ability to allow the researchers to observe and analyse a case that may not have been previously examined [18].

The case study was conducted in an automobile manufacturing company that has operations in different countries, including South Africa. The manufacturing operation in South Africa consists of four main production departments: physical logistics, the body shop, the paint shop, and the assembly plant. The physical logistics department is responsible for overall plant logistics, and has four sections, with a manager and team leader for each section.

The body shop department is primarily responsible for building the structural components of vehicle bodies. It has three sections, each with a manager and team leader. The paint shop department is responsible for the paint application processes for the units; whereas the assembly plant department assembles the parts and components of the unit. Each of these departments has various sections, each with their own managers and team leaders.

Data collection was effected through self-administered questionnaires and document analysis.

\subsection{Questionnaire}

A questionnaire is one of the most popular data-collection methods employed in sourcing primary data [17]. It comprises a set of well-constructed questions that have been developed to derive data in order to address the research objectives [17]. The research questions were extracted from the literature survey, and tested the factors of the study: the standard work for leaders and unused employee creativity. Self-administered questionnaires were selected due to their ease of use, their perceived anonymity, and the fact that the participants could thoroughly think through their responses [19].

\subsubsection{Questionnaire design}

The questionnaire had four sections, each of which was identified to test different elements of the literature in line with the research objectives. The four elements were lean tools and techniques, employee creativity, lean leadership, and standard work for leaders. The four sections were as follows:

- $\quad$ Section A: Background information;

- $\quad$ Section B: Lean knowledge;

- $\quad$ Section C: Standard work for leaders and employee creativity (only for process supporters and operators); and

- $\quad$ Section D: Standard work for leaders and employee creativity (only for team leaders and managers).

\subsection{Document analysis}

'Document analysis' refers to a logical process of evaluating various documents in order to deduce meaning, thus reaching a deduction about a certain subject [21]. Analysing documents can aid in providing data that is specific to the context of the respondents or organisation [21]. In this study, document analysis was conducted on the process improvement sheets in the different departments. In each of the process supporter teams there is a document that captures the operators' improvement ideas. The document is placed on the team boards on the shop floor to enable ease of access and visibility for the process supporters and the operators.

In each of the four departments, four process supporter teams were selected at random, and the process improvement sheets (documents) were analysed over a six-month period (displayed as two quarters). On each of the process improvement ideas sheets, the information that was assessed was the number of ideas suggested per team. This information was analysed in relation to the questionnaire. This enabled the researchers to determine the connection between the number of improvement ideas on the process improvement sheet and whether standard work for leaders was in place, according to the results of the questionnaire. 
Table 2. Sample questionnaire used for team leaders and managers

\begin{tabular}{|c|c|}
\hline Element & Questionnaire \\
\hline Profile & $\begin{array}{l}\text { Request the respondent to rank level of lean knowledge. } \\
\text { Determine if respondent attended lean training, if so ask to rate the lean training } \\
\text { attended. }\end{array}$ \\
\hline $\begin{array}{l}\text { Team leaders and } \\
\text { managers sample }\end{array}$ & $\begin{array}{l}\text { My role as a leader is to enable my employees to improve processes. } \\
\text { My role as a leader is to enable my employees to solve problems. } \\
\text { I attend daily Gemba walks. } \\
\text { I support the workers through daily interactions so that they can creatively think of } \\
\text { solutions to solve their problems. } \\
\text { I can show recent improvements that were implemented as a result of suggestions from } \\
\text { workers. } \\
\text { I teach the workers lean through daily actual problem-solving on the shop floor. } \\
\text { My workers are trained on the basic lean tools. } \\
\text { My workers are able to improve processes using simple lean tools. } \\
\text { I spend time on the shop floor daily, in order to understand the actual situation through } \\
\text { process observation, instead of relying only on reports. } \\
\text { I coach my workers regularly. } \\
\text { During coaching sessions, the coachee is the one who finds the solution. } \\
\text { Through regular coaching, my workers take more initiative to develop ideas more } \\
\text { frequently. } \\
\text { Through standardised work, I ensure that my workers are working according to the } \\
\text { standard processes. } \\
\text { I have a structured standard floor time for coaching and training my workers daily. } \\
\text { My employees are responsible for problem-solving. } \\
\text { My employees are responsible for continuous improvement. } \\
\text { My employees are responsible for process confirmation. } \\
\text { My workers are the process experts; thus their ideas are always solicited for problem- } \\
\text { solving. } \\
\text { My workers are process experts; thus their ideas are always solicited for continuous } \\
\text { improvement. } \\
\text { Process improvement initiatives are spread across the organisation, including the } \\
\text { workers; thus their implicit skills and knowledge are fully utilised. }\end{array}$ \\
\hline
\end{tabular}

\subsection{Data validity}

The research questions were derived from the literature review; the respondents to the questionnaire (the units of analysis) were people holding similar positions in the organisation from different business units; and document analysis was conducted to confirm or contradict the findings from the research questionnaires.

\section{RESULTS}

Table I indicates the distribution of the questionnaires and the responses received per department. From the total sample size of one hundred and forty-five, twenty-three questionnaires were not returned, and eleven were not completed fully. Thus only one hundred and eleven questionnaires were considered. The highest contribution of respondents to the study was from the operators, who constituted 45 per cent of the total study.

\subsection{Department of Physical Logistics}

The questionnaire results indicated that standard work for leaders in the physical logistics department was not optimally implemented. The department considered it part of employees' responsibility to improve processes and solve problems; but the employees did not perceive that their ideas were solicited or considered during process improvement and problem-solving.

In addition, a significant number of the workers from physical logistics had not attended previous lean training, and so their lean knowledge was low. It was concluded that physical logistics does not optimally use the creativity of their employees, and that effective coaching had not been implemented. 
Table 3: Distribution of questionnaires and respondents

\begin{tabular}{|l|c|c|c|}
\hline Role & No. of questionnaires & No. of respondents & \% respondents \\
\hline Operator & 99 & 65 & $45 \%$ \\
\hline Process supporter & 21 & 21 & $14 \%$ \\
\hline Team leader & 15 & 15 & $10 \%$ \\
\hline Manager & 10 & 10 & $7 \%$ \\
\hline Incomplete questionnaires & & 11 & $\mathbf{8} \%$ \\
\hline Unreturned questionnaires & & 23 & $16 \%$ \\
\hline Total & $\mathbf{1 4 5}$ & $\mathbf{1 1 1}$ & $\mathbf{1 0 0 \%}$ \\
\hline
\end{tabular}

\subsection{Bodyshop Department}

Standard work for leaders in the bodyshop department was not comprehensively implemented. The bodyshop department also considered it part of employees' responsibility to improve processes and to solve problems; but again, the operators did not perceive that their ideas were considered or used during process improvement and problem-solving initiatives. However, the operators from the department had been trained in lean, and were able to improve processes using the simple lean tools - and they demonstrated recent improvements that were implemented as a result of their suggestions.

Although the bodyshop department had implemented certain elements of standard work for leaders, it was not comprehensively implemented. Furthermore, although much lean training had been conducted in this department, the ideas of the employees were not fully used, and effective coaching was not implemented.

\subsection{Paint Shop Department}

The questionnaire results indicated that the paint shop department had implemented more elements of standard work for leaders than either the physical logistics and the bodyshop department. However, the operators from the paint shop also indicated that they did not perceive that their ideas were solicited or employed for problem-solving and continuous improvement; nor was effective coaching implemented.

\subsection{Assembly Department}

The results confirmed that the assembly department had implemented standard work for leaders more comprehensively than the other departments. However, the coaching element was still lacking in the assembly department. A significant number ( 50 per cent) of the operators indicated that they perceived that their ideas were employed for continuous improvement and problem-solving.

Finally, in response to the first research objective, it was concluded that the assembly plant had implemented standard work for leaders the most comprehensively.

\subsection{Document analysis}

Document analysis was one of the techniques employed for data collection. Its purpose was to analyse the documents (in section 3 ) to determine the number of ideas that had been suggested per department over a period of six months. In each department, four process supporter team boards were selected, and the number of ideas suggested were compared with the number of ideas implemented. The results are presented in Figure 2.

Figure 2 indicates that the assembly department had consistently suggested and implemented a larger number of ideas over the selected time period; by contrast, the department of physical logistics had suggested and implemented the lowest number of ideas. The results established that the physical logistics department had not optimally employed the creativity of their employees, confirming, as determined by the research questionnaires, that standard work for leaders was not comprehensively applied. The documentation analysis responded to and resolved the second research objective of the study. 


\section{Document analysis}

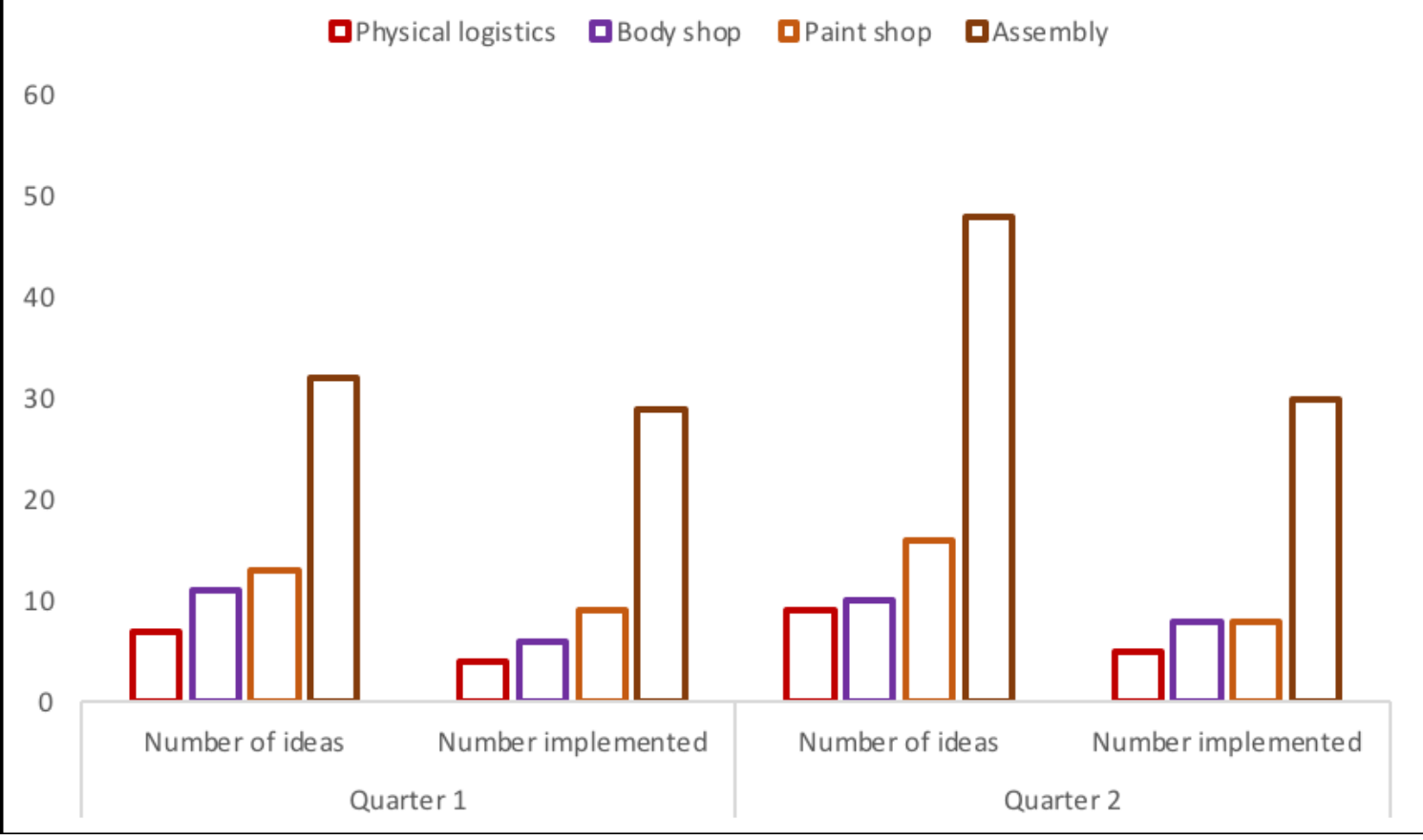

Figure 2: Document analysis: Number of improvement ideas per department

\section{DISCUSSION OF RESULTS}

The literature review indicates that the eighth waste of lean (unused employee creativity) is not effectively addressed during lean implementation. The premise of this study was to determine whether standard work for leaders could reduce unused employee creativity and therefore reduce waste. The study was conducted in four departments in an automobile manufacturer in South Africa.

The first research objective was to determine which of the four departments had more comprehensively implemented standard work for leaders. The objective was tested with a research questionnaire that was submitted to respondents from each of the four departments.

The second research objective was to investigate which of the four departments had the highest number of improvement ideas that had been suggested and implemented. The objective was tested with document analysis over a period of six months. The results of both the research questionnaire and the document analysis confirmed that the assembly department had implemented standard work for leaders more comprehensively than physical logistics, the body shop, or the paint shop, and that they were actively harnessing the creativity of their employees and the improvement ideas they suggested. The opposite was true for the department of physical logistics: standard work for leaders was not optimally implemented, and so they did not engage the creativity of their employees. The department considered it employees' responsibility to improve processes and to solve problems; but the employees did not perceive that their ideas were solicited or considered during process improvement and problem-solving.

The findings from the case study determined that, whenever standard work for leaders is comprehensively implemented, and the employees have been trained in lean, the number of improvement ideas increases. In summary, standard work for leaders can assist in increasing employee creativity during lean implementation.

\section{RECOMMENDATIONS}

The following recommendations were suggested to the organisation after the completion of the study: 
- $\quad$ Comprehensively implement standard work for leaders in the department of physical logistics, the body shop, and the paint shop.

- Develop a training plan to ensure that all operators are trained in lean.

- Develop coaching training for all the departments, all of which indicated that coaching was ineffectively executed. The training would enable the leaders to develop standard work elements and assist in challenging the employees to develop more ideas for improvement.

In addition to the recommendations, a lean implementation model was developed from the literature study, the results of the questionnaire, and the document analysis. The model is presented in Figure 3.

The purpose of the model was to demonstrate the relationship between lean leadership (with an emphasis on standard work for leaders), lean tools and techniques, and employee creativity. Standard work for leaders is a part of lean leadership, and thus is complemented by other elements in the lean leadership framework. However, for the purposes of this research, standard work was emphasised in the model.

At the core of the lean production system are people [12]. The premise of this notion is that people are the only ones who can think, learn, and develop. Therefore, when leaders practise standard work, and the lean tools and techniques are invested in the employees, they are challenged to solve problems and to improve processes, and their creativity is harnessed. Furthermore, the ideas that result from employee creativity require the necessary leadership support to ensure that they are evaluated and eventually implemented [20].

The research results indicated that a comprehensive application of standard work for leaders and of lean training encourages employee creativity. Consequently, the lean implementation model was developed as a representation of the results. The researchers recommend that the model be implemented and validated to confirm its wider application and the generalisability of the research findings.

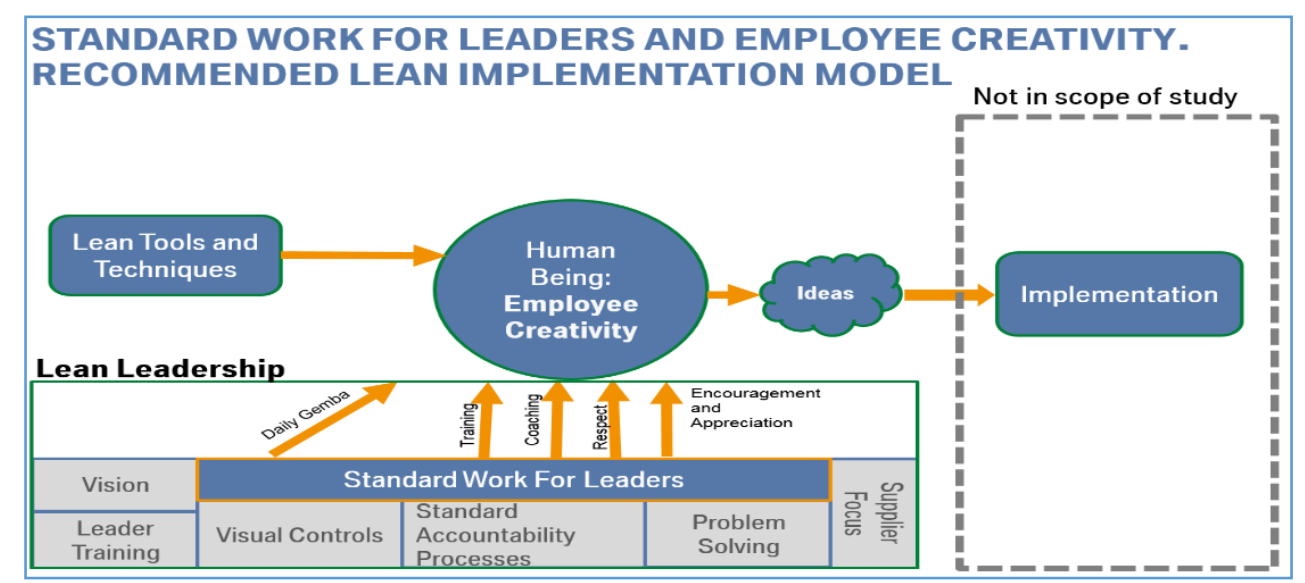

Figure 3: Recommended lean implementation model

\section{CONCLUSION}

The purpose of the study was to investigate the impact of standard work of leaders in minimising or eliminating the waste of unused employee creativity. A systematic research process was followed to test and validate the research objectives.

The research results indicated that, in order fully to enjoy the benefits of standard work for leaders, the elements of standard work for leaders have to be comprehensively implemented. It was also determined that employees must be trained in lean techniques to contribute significantly to lean improvement. Leaders are required to provide the necessary support structure, through standard work for leaders, to cultivate employee creativity. Whenever standard work for leaders was not comprehensively implemented, the number of improvement ideas was low, and vice versa. The effective implementation of standard work for leaders can therefore positively improve employee creativity. 


\section{REFERENCES}

[1] Van der Merwe, K.R., Pieterse, J.J. and Lourens, A.S. 2014. The development of a theoretical lean culture causal framework to support the effective implementation of lean in automotive component manufacturers. South African Journal of Industrial Engineering, 15(1), pp.131-144.

[2] Rother, M. 2009. Toyota Kata: Managing people for improvement, adaptiveness and superior results. McGrawEducation.

[3] Harald, K., Merel, K., Guy, V. and Widdershoven, A. 2015. Lean leadership: An ethnographic study. Leadership in Health Services, 28(2), pp. 119-134.

[4] Mann, D. 2009. The missing link: Lean leadership. Frontiers of Health Services Management, 26(1), pp. 15-26.

[5] Poksinska, B., Swartling, D. and Drotz, E. 2013. The daily work of lean leaders: Lessons from manufacturing and healthcare. Total Quality Management, 24(8), pp. 886-898.

[6] Mann, D. 2010. Creating a lean culture: Tools to sustain lean conversions (2nd ed.). New York: Productivity Press.

[7] Emiliani, M. 2013. Standardized work for executive leadership. Leadership and Organization Development Journal, 29(1), pp. 24-46.

[8] Jyoti, J. and Dev, M. 2015. The impact of transformational leadership on employee creativity: The role of learning orientation. Journal of Asia Business Studies, 9(1), pp. 78-98.

[9] Liker, J.K. and Meier, D. 2006. The Toyota way fieldbook: A practical guide for implementing Toyota's 4Ps. McGraw-Hill.

[10] Wee, H. and Wu, S. 2009. Lean supply chain and its effect on product cost and quality: A case study on Ford Motor Company. Supply Chain Management: An International Journal, 14(5), pp. 335-341.

[11] Saurin, A.T., Marodin, G.A. and Ribeiro, L.D. 2011. A framework for assessing the use of lean production practices in manufacturing cells. International Journal of Production Research, 49(11), pp. 3211-3230.

[12] Radnor, Z. 2011. Implementing lean in health care: Making the link between the approach, readiness and sustainability. International Journal of Industrial Engineering and Management, 2(1), pp. 1-12.

[13] Dibia, I.K., Dhakal, H.N. and Onuh, S. 2014. Lean leadership people process outcome (LPPO) implementation model. Journal of Manufacturing Technology Management, 25(5), pp. 694-711.

[14] Spear, S.J. 2004. Learning to lead at Toyota. Harvard Business Review, May, pp. 1-9.

[15] Goodridge, D., Westhorp, G., Rotter, T., Dobson, R. and Bath, B. 2015. Lean and leadership practices: Development of an initial realist program theory. BMC Health Services Research,15(362), pp. 1-15.

[16] Urban, W. 2015. The lean management maturity self-assessment tool based on organizational culture diagnosis. Procedia - Social and Behavioral Sciences, 213, pp. 728-733.

[17] Wilson, J. 2014. Essentials of business research: A guide to doing your research project (2nd ed.). London: SAGE Publications.

[18] Saunders, M., Lewis, P. and Thornhill, A. 2012. Research methods for business students (6th ed.). Harlow: Pearson Education Limited.

[19] Cooper, D.R. and Schindler, P.S. 2006. Business research methods (9th ed.) New York: McGraw-Hill International Edition.

[20] Steyn, J.L. and Buys, A.J. 2011. Creativity and 'eureka' in science and engineering. South African Journal of Industrial Engineering, 22(2), pp.1-17.

[21] Bowen, G.A. 2009. Document analysis as a qualitative research method. Qualitative Research Journal, 9(2), pp. 27-40. 